\title{
Can Public Expenditures and Foreign Direct Investment Sustain Cameroon's Agricultural Growth in the Next two (2) Decades? Forecasting Using Ordinary Differential Equation: 2016-2035
}

\author{
Djomo Raoul Fani*, Odoemenem Uwaegbuonu Innocent, Aye Goodness Chioma and Abu Orefi \\ Department of Agricultural Economics, Federal University of Agriculture, Nigeria
}

Submission: July 12, 2016; Published: July 19, 2017

"Corresponding author: Djomo Raoul Fani, Department of Agricultural Economics, Federal University of Agriculture, Nigeria,

Email: raoulfani@gmail.com

\begin{abstract}
Sustainable development through public expenditures and foreign direct investment raise questions over time owing that agriculture is the backbone of the Cameroon's economy, as it contributes significantly to the economy growth of the country. Therefore, this study was carried out to ascertain whether public expenditures and foreign direct investment can sustain Cameroon's agricultural growth in the next two (2) decades. Data were collected from secondary sources, analyzed using ordinary differential equation. It was found that in the next two (2) decades the agricultural growth will be estimated at $638,408,834,199,374$ tons which represent $99.99 \%$ growth rate from 2016 to 2035 . It was recommended that tax should be reduced to attract more foreign investor in the country. Further, investment on capital expenditures should be increased while appropriate monitoring and evaluation should follow up the process.
\end{abstract}

Keywords: Public expenditures; Foreign direct investment; Agricultural growth

\section{Introduction}

Since devaluing its currency in January 1994, Cameroon's economy has rebounded with annual growth in the range of 4 to 5 per cent. However, the country is one of the best-endowed primary commodity economies in Sub-Saharan Africa. It has modest oil resources and favorable agricultural conditions. Although oil production is in decline, it continues to play a key role in the country's economy, representing 10\% of GDP and around $40 \%$ of both fiscal and export revenues (2008). The dependency on oil and soft commodity prices has also caused macroeconomic performance to be volatile and uneven (Van den Akers, 2010). Lower global demand and lower prices of commodities lead to lower growth and trade revenues for these sectors in 2009. With exports falling sharply (13\% in real terms and $40 \%$ in nominal USD terms), the economy contracted by over $1 \%$, down from a positive $3.3 \%$ in 2008 , against an anticipated growth of 2\% for 2009. GDP growth prospects for 2010 and 2011 indicate a continuation of a slow pace of recovery relative to its peer group in Africa, where growth remained positive in 2009. With exports forecast to continue to decline (Van den Akers, 2010). The government faced with the challenge of reducing the budget deficit, cut non-wage expenditures (operations and maintenance) and capital investments rather than to reduce the size of the civil service. However, reflecting increasing donor funding as well as domestic resource mobilization, capital expenditure increased from one percent of GDP in 1996 to more than 3 percent in 2002. In the last few years, to balance expenditure, the Government has continued to squeeze capital expenditures, to 1.8 percent o f GDP in 2004 [1]. In order to tap the country's major development potential, the Government of Cameroon drew up a second-generation poverty reduction strategy paper in 2009, the growth and employment strategy paper (DSCE) which covers the period 2010 to 2020. Focused on spurring growth, creating formal employment and reducing poverty, the DSCE highlights the Government's commitment to the achievement of the Millennium Development Goals. Regional integration and better governance, especially fighting corruption, transparency in the markets and a more conducive business environment are the priority issues of the DSCE [2]. The role of foreign direct investment (FDI) is widely recognized as a factor which promotes growth in developing countries, and the relationship between FDI and economic growth has given 
rise to a vast empirical literature focused both on developed and developing countries. Neoclassical and endogenous growth models have been the starting point for many empirical studies on the link between FDI and growth (Ambon, 2013). Given the past and the current development paradigm, private sector with private capital is one of the key engines for economic growth in Africa. Faced with economic crisis, Cameroon resorted to the lobbying and encouragement of foreign aids, foreign investment and export oriented production as panacea for sustainable economic growth that could be trickled down to poverty reduction. Many macroeconomic measures and institutional reforms became fashionable and with the assistance of the World Bank, the Structural Adjustment Program (SAP) was adopted and ushered into the economic growth and sustainable development agendas of Cameroon [3].

Agriculture remains a key sector of the economy making Cameroon, unlike its neighbors, self-sufficient in food. Over twothirds of the working population is employed in agriculture, and the sector contributes about a quarter of value added and brings in a third of export earnings (African Economic Outlook, 2003). Favorable weather conditions prevailing since the mid-1990s, have resulted in a steady increase in food crop production ( 5 per cent in 2001/02). Contrast, export crops have suffered from low world prices (particularly affecting coffee), ageing plantations (with uncertainty regarding privatization also affecting rubber) and disruptions in the cocoa and coffee sectors after liberalization. As a result, young farmers are replacing export crops in favor of food crops [4]. Over years, the government of Cameroon through its macroeconomics policy attempted to stimulate growth in the economy which is necessary to generate resources required for future spending. Therefore, this study was carried out to ascertain whether public expenditures and foreign direct investment can sustain Cameroon's agricultural growth in the next two (2) decades.

\section{Methodology}

\section{The study area}

The study was conducted in Cameroon which has ten regions, namely: Centre; Littoral; Adamawa; Far-North; North; South; East; West; North-West and South-West. The country covers a total land area of $475,442 \mathrm{sq} \mathrm{km}$ and is located in the Central part of Africa within latitudes $2^{\circ}$ and $13^{\circ}$ North and longitude $9^{\circ}$ and $16^{\circ}$ East of the equator (United Nations, 2004). Cameroon is bordered by Nigeria to the West; Chad to the Northeast; the Central Africa Republic to the East and Equatorial Guinea, Gabon and Republic of Congo to the South (World facts book, 2010).

\section{Method of data collection}

Secondary data consisting of annual time series covering a period of 32 years (1985-2016) were obtained from World Bank development indicators data base, Ministry of Economic and Planning. Food and Agriculture Organization, World Atlas data base and United Nations Organization of trade.

\section{Techniques of data analysis}

Ordinary Differential Equation was used to forecast agricultural growth in the next two (2) decades.

\section{Model Specifications}

Forecasting Equation of Agricultural Growth in the next Two (2) Decades with respect to Public Expenditures and Foreign Direct Investment

$\mathrm{dAgric} / \mathrm{dt}=\beta \_1$ fds $+\beta \_2$ fdi $+\beta \_3$ puexp $+\beta \_4$ gorev $+\beta \_5$ gdpi $+\beta \_6$ workf .

By differentiating public expenditures and private investment with respect to time in equation (1), the differential equation for forecasting of agricultural growth is defined as follow:

$\mathrm{dAgric} / \mathrm{dt}=\mathrm{df}(\mathrm{fdi}$,puexp) $/ \mathrm{dt}$...

Where : $\mathrm{t}=$ period agricultural growth (agric) is measured in tons food supply (fds) is measured in tons government revenue (gorev) is measured in cfa gross domestic private investment (gdpi) is measured in cfa work force (work f) is measured per thousands Foreign direct investment (fdi) is measured in cfa public expenditure (puexp) is measured in cfa

\section{Results and Discussion}

\section{Forecast of cameroon's agricultural growth in the next two (2) decades}

The forecast of agricultural growth in the next two (2) decades is shown in Figure 1. Figure 1 showed that in the next two (2) decades, the Cameroon's agricultural growth will be estimated at $638,408,834,199,374$ tons which represent 99.99\% growth rate. This may be attributed to the fact this forecast did not take into consideration environmental factors and the others factors that could affect the agricultural growth which may have influenced the value of the forecast. This result is above the value obtained by Nkwatoh [5] who found 6.5\% growth rate for the Cameroon's economy by 2035. Specifically, from 2016 to 2020, the agricultural growth will decreased from $2,994,370,911$ tons to $1,069,011,258$ tons; from 2021 to 2025 , the agricultural growth will increased from $1,871,488,611$ tons to $43,673,179,098$ tons; from 2026 to 2032 , the agricultural growth will decreased from $12,264,809,714$ tons to $1,400,366,745$ tons; from 2033 to 2035, the agricultural growth will increased from $1,516,999,185$ tons to $638,408,834,199,374$ tons $[6,7]$. 


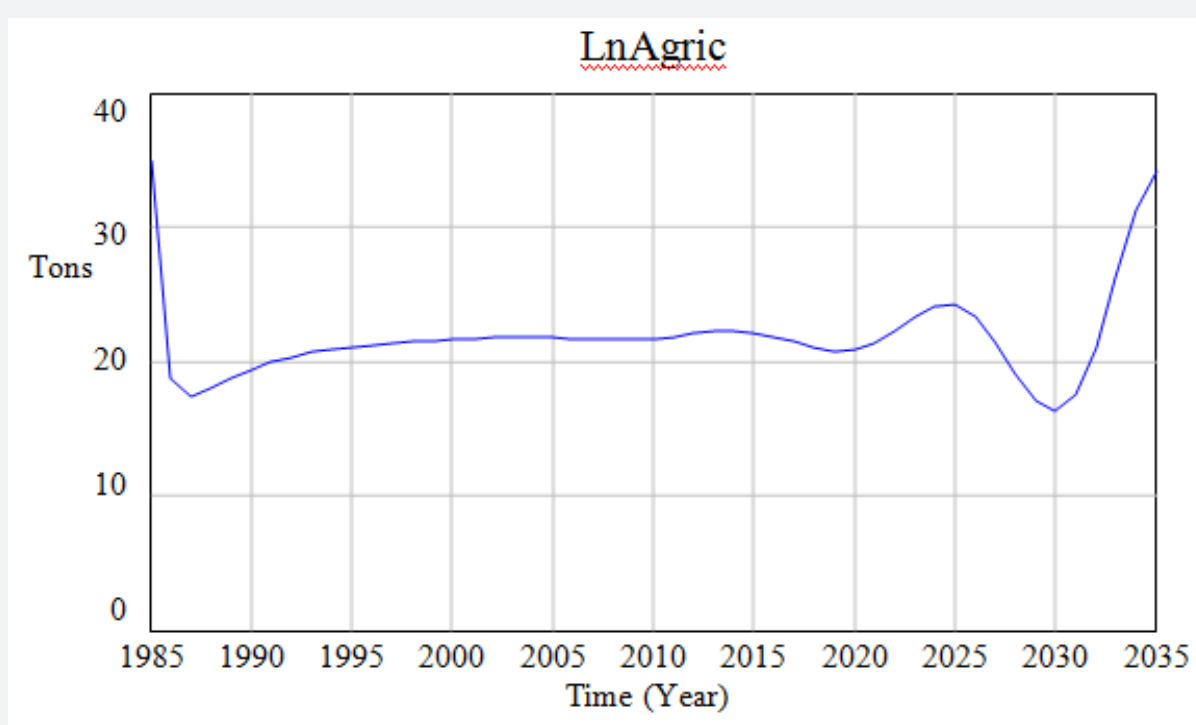

Agric: baseline

Figure 1: Cameroon's agricultural growth in the next two (2) decades.

\section{References}

1. World Bank (2006) Cameroon-public expenditure management and financial accountability review (PEMFAR). Washington, USA.

2. International Fund for Agricultural Development (2012) Enabling poor rural people to overcome poverty: 1-12. IFAD, USA.

3. Abit MO (2014) Export-Income, Economic Growth and Poverty Reduction in Cameroon. Clarion University of Pennsylvania, Clarion, Pennsylvania, USA, 16(7): 53-78.
4. African Economic Outlook (2003) An overview of Cameroon's economy. AfDB/OECD: 1-12.

5. Nkwatoh LS (2016) Can Cameroon become an emerging economy by the year 2035? Projections from univariate time series analysis. Journal of economics and international finance 8(10): 155-167.

6. Fambon S (2013) Foreign Capital Inflow and Economic Growth in Cameroon. Wider Working Paper No (124): 1-22.

7. Akker VDJ (2010) Country report Cameroon, Country Risk Research Economic Research Department. Rabobank Netherland, pp. 1-7.

Your next submission with Juniper Publishers
will reach you the below assets
- Quality Editorial service
- Swift Peer Review
- Reprints availability
- E-prints Service
- Manuscript Podcast for convenient understanding
- Global attainment for your research
- Manuscript accessibility in different formats
( Pdf, E-pub, Full Text, Audio)
- Unceasing customer service
Track the below URL for one-step submission
https://juniperpublishers.com/online-submission.php

